\title{
Effect of warm water on postharvest quality of cut rose (Rosa hybrida L.) flowers
}

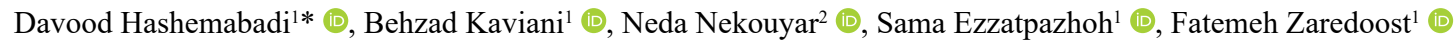 \\ ${ }^{1}$ Department of Horticulture Science, Rasht Branch, Islamic Azad University, Rasht, Iran. \\ ${ }^{2}$ Department of Horticulture Science, Science and Research Branch, Islamic Azad University, Tehran, Iran.
}

\begin{abstract}
Rose is an ornamental plant, which constitutes one of the leading cut flowers in the world. The vase life of cut Rosa hybrida L. flowers is truly short. We examined the effect of various temperatures and different time duration factors on postharvest longevity, and some other physic-biochemical characteristics and antioxidants activity. Fresh cut Rosa hybrida L. flowers were treated by water with various temperatures $\left(23^{\circ}, 42^{\circ}, 47^{\circ}\right.$, and $\left.52^{\circ} \mathrm{C}\right)$ and different time duration $(5,10,15$, and 20 min). Maximum vase life (7.52 days) was related to cut flowers that were treated with $52^{\circ} \mathrm{C}$ for $15 \mathrm{~min}$. Minimum vase life (4.46 days) was observed in cut flowers that were treated with $42^{\circ} \mathrm{C}$ for $5 \mathrm{~min}$. Treatment of cut flowers by water with the temperature of $52^{\circ} \mathrm{C}$ for 15 min induced the highest water absorption, petal's anthocyanin, and leaf's chlorophyll. The lowest ethylene production was also obtained in cut flowers treated with $52^{\circ} \mathrm{C}$ for $15 \mathrm{~min}$. The use of warm water $\left(52^{\circ} \mathrm{C}\right)$ for $15 \mathrm{~min}$ clearly extended the vase life and most traits pertaining to the vase life of cut Rosa hybrida L. flowers.
\end{abstract}

Keywords: ethylene; heat treatment; ornamental plants; rose; vase life; water absorption.

\section{Resumo}

Efeito da água quente na pós-colheita de rosas de corte (Rosa hybrida L.)

A rosa é uma planta ornamental que representa uma das espécies mais importantes de flores de corte do mundo. A vida de vaso de hastes florais de Rosa hybrida L. é muito curta. Foram examinados os efeitos de diversas temperaturas de água e tempos de exposição na longevidade pós-colheita, em algumas outras características físico-químicas e na atividade antioxidante. Flores recém-cortadas de $R$. hybrida L. foram tratadas com água quente em diferentes temperaturas $\left(23^{\circ}, 42^{\circ}, 47^{\circ}\right.$ e $\left.52^{\circ} \mathrm{C}\right)$ e expostas por diferentes tempos $(5,10,15$ e $20 \mathrm{~min})$. A vida de vaso máxima (7.52 dias) foi determinada quando as flores foram tratadas com água à $52^{\circ} \mathrm{C}$ por $15 \mathrm{~min}$. A vida de vaso mínima (4.46 dias) foi observada quando as flores foram tratadas com 42 ${ }^{\circ} \mathrm{C}$ por $5 \mathrm{~min}$. $\mathrm{O}$ tratamento de $52^{\circ} \mathrm{C}$ por $15 \mathrm{~min}$ também induziu maior absorção de água e maiores conteúdos de antocianina nas pétalas e clorofila nas folhas. Uma menor produção de etileno também foi encontrada no tratamento $52^{\circ} \mathrm{C}$ por 15 min. $\mathrm{O}$ uso de água quente $\left(52^{\circ} \mathrm{C}\right)$ por 15 min claramente estendeu a vida de vaso e melhorou outras características potencialmente relacionadas à vida de vaso de hastes de $R$. hybrida $\mathrm{L}$.

Palavras-chave: etileno; tratamento por calor; plantas ornamentais; rosa; vida de vaso; absorção de água.

\section{Introduction}

Rose (Rosa hybrida L.), from the family Rosaceae is used as cut flowers, garden and potted plants, and as well as for medicinal, industrial, and perfume purposes. The widest use of rose is cut flower (Leus et al., 2018). The vase life of cut flowers is an important factor in the determination of economic values. The vase life of cut roses is short due to wilting, ethylene production, and vascular blockage by air and microorganisms (Ghadimian and Danaei, 2020). Generally, after harvest, preservation water balance is a major parameter in specifying the quality and longevity of cut flowers (Lu et al., 2020). Microorganisms, which grow in preservative solutions, are among the major parameters that can block xylem vessels, decreasing water uptake and the postharvest life of cut flowers (Kazaz et al., 2019). The growth of microorganisms in the vase solution can also increase the production of ethylene and secrete toxic compounds (Minde, 2019).

*Corresponding author: davoodhashemabadi@yahoo.com 
Heat treatment offers a pathogens-free method and maintains postharvest quality (Francesco et al., 2018). Heat treatment is an environmental-friendly technology to extend postharvest life of different products. Heat treatments cause a cut off of the normal metabolism on the senescence stage or ripening of the plant products, and preserve postharvest life for a longer time (Perini et al., 2017; Zhang et al., 2019). Perini et al. (2017) reported that application of hot water $\left(50{ }^{\circ} \mathrm{C}\right.$ for $\left.3 \mathrm{~min}\right)$ delays broccoli senescence. Hot water also enhanced postharvest quality and antioxidant enzymes activities of oranges varieties (Bassal and ElHamahmy, 2011). Nasef (2018) reported that short periods of hot water dipping of cucumber could maintain quality and prevent decay in the cold-stored period. The positive effect of hot water was showed on postharvest characteristics of zucchini fruit during cold storage (Zhang et al. (2019).

Studies about the effect of heat treatments on enhancing the quality of vase life of cut flowers are limited. Heat treatments have been shown to be effective for disinfestation treatments in some flowers (Hara et al., 1997). Thus, hot water has the potential to prolong the vase life of some cut flowers. The present work aimed to evaluate the effect of warm water and its application time on the postharvest quality of Rosa hybrid L.

\section{Materials and Methods}

\section{Plant material}

Cut rose (Rosa hybrida L., cv. Cyclamei) flowers were procured from plants grown in a greenhouse in Mahalat (longitude: 335', geographical width: $50^{\circ} 27^{\prime}$ and longitude from the sea level: $1,775 \mathrm{~m}$ ), Iran. They were immediately sent in buckets to the postharvest laboratory. Buckets containing the flower stems were covered with a plastic film shroud to hinder moisture loss during transportation. At the laboratory, stems were re-cut under $4^{\circ} \mathrm{C}$ deionized water to $\sim 50 \mathrm{~cm}$ length to remove air emboli. All leaves that were grown below the fourth node on the stems were removed. The flowers were selected in terms of uniformity of size, color and freedom from any defects. Cut flowers were placed in plastic pots containing $500 \mathrm{~mL}$ water and sucrose $3 \%$ as continuous treatment in March 2020.

\section{Experimental design and treatments}

The experimental design was factorial, based on a randomized completely blocks design (RCBD) with 16 treatments through one harvest on March 2020. The first factor was 4 levels of water at different temperatures $\left(23^{\circ}\right.$, $42^{\circ}, 47^{\circ}$, and $\left.52^{\circ} \mathrm{C}\right)$. The second factor was 4 levels of time duration $(5,10,15$, and $20 \mathrm{~min})$. The experiment was done with 3 replications, 48 plots, and 240 flowers bunch. Each plot contained five cut rose flowers. After treatments, cut rose flowers were placed in pots filled with distilled water with the temperature of $20-25^{\circ} \mathrm{C}$ for $15 \mathrm{~min}$, followed by kept in vase pot for drying. Then, cut flowers were hold in pots containing $500 \mathrm{~mL}$ water and sucrose $3 \%$ as continuous treatment. The flowers were kept in a vase life (controlled environment) room under the following conditions: $\quad 18 \pm 2 \quad{ }^{\circ} \mathrm{C}, \quad 60 \%-70 \%$ relative humidity, $12 \mu \mathrm{molm}^{-2} \mathrm{~s}^{-1}$ light intensity (cool white florescent tubes), and a daily light period of 12-h.

\section{Measurement of traits}

The vase life of cut flowers was evaluated on a daily basis until the end of the vase life duration. Vase life was supposed to be ended when visible signs of petal's wilting appeared. A digital balance was used to determine fresh weight. The first measurement was done just after the pulse treatment; the last measurement was recorded on the last day of vase life. Then, the final weight was subtracted from the first one to yield fresh weight loss. At the end of flower vase life, flowers of each treatment were weighed, and then they were oven-dried for $24 \mathrm{~h}$ at $70^{\circ} \mathrm{C}$ to reach a constant weight. The dry matter percentage of cut flowers was calculated as per the Equation 1:

Dry matter $(\%)=$ Dry weight $/$ fresh weight $\times 100$

The 4 dishes with $500 \mathrm{ml}$ distilled water had been placed between the pots containing cut flowers to determine the evaporation of vase solutions. The content of these dishes was weighted on the last day of each plot's vase life, and the solution uptake was estimated for each plot by the following expressions: (500 - the reduced content of a solution in the dishes at the last day of vase life + the surface evaporation of the last day=Y). Then, Y was divided by the first-day flower fresh weight of each plot and multiplied by 100: (Y/the first day fresh weight); this data is solution uptake per plot $\left(\mathrm{mL} \mathrm{g}^{-1} \mathrm{FW}\right)$. A drop of recuts water of stem end was put on the glass sheet of the refractometer (Atago N-1 $\alpha$ model) at the first and last days of vase life of cut flowers. The last ${ }^{\circ}$ Brix was subtracted from the first one to yield ${ }^{\circ}$ Brix of the cut flower. On the $5^{\text {th }}$ day of vase life, one cut flower was taken from each plot, and its petal's anthocyanin was measured based on Mazumdar and Majumder (2003) method. At the end of cut flower life, a flower was removed from each plot to measure leaf chlorophyll content. Photosynthetic pigments were extracted first. One gram of leaf was ground in liquid nitrogen using a mortar and pestle. The $10 \mathrm{~mL}$ of $80 \%$ acetone was added to a $15 \mathrm{~mL}$ Falcon tube, and mixed in the dark for $15 \mathrm{~min}$. The mixture was filtered through two Whatman filter papers. The absorbance of chlorophyll was measured with three replications at two wavelengths, 642.5 and $660 \mathrm{~nm}$, using spectrophotometry.

To measure the amount of released ethylene by cut flowers, after exposure to treatments, a cut flower was selected from each plot on second day and placed in a jar. The mouth of the jars was sealed to prevent air movement. After 12-h, the gas from inside the jar was sampled and sent to laboratory analysis. Ethylene production was measured with GC-AIT 8, manufactured by Schimadzu Corporation, Japan. Lipid peroxidation was assessed using the Bates et al. (1973) method. Petal samples (0.5 g) were homogenized in $1 \mathrm{~mL}$ of $0.1 \%$ trichloroacetic acid (TCA). The homogenate was centrifuged at $14,000 \mathrm{~g}$ for $15 \mathrm{~min}$, and then $500 \mu \mathrm{L}$ of supernatant was added to $500 \mu \mathrm{L}$ of $0.5 \%$ thiobarbituric acid 
(TBA) in $20 \%$ TCA. The mixture was heated at $95^{\circ} \mathrm{C}$ for 30 min and then cooled in an ice bath. After centrifugation at $10,000 \mathrm{~g}$ for $10 \mathrm{~min}$, the absorbance of the supernatant was calculated at $532 \mathrm{~nm}$. The MDA content was measured when the extinction coefficient of the sample was $155 \mathrm{mM} \mathrm{cm}^{-1}$ (Heath and Parker, 1968). Each extract used for POD activity measurement was prepared by freezing $0.5 \mathrm{~g}$ of petal tissue in liquid nitrogen and then grinding the tissue in $10 \mathrm{ml}$ of extraction buffer $[50 \mathrm{mM}$ phosphate buffer, $\mathrm{pH} 7$ containing $0.5 \mathrm{mM}$ EDTA and 2\% PVPP $(\mathrm{w} / \mathrm{v})]$. The resulting homogenate was centrifuged for $20 \mathrm{~min}$ at $15,000 \mathrm{~g}$, and the supernatant was used to determine enzymatic activity. POD activity was assayed with spectrophotometric measurement of guaiacol formation in $1 \mathrm{~mL}$ of a reaction mixture, consisting of $450 \mu \mathrm{L}$ of $25 \mathrm{mM}$ guaiacol, $450 \mu \mathrm{L}$ of $225 \mathrm{mM}$ $\mathrm{H}_{2} \mathrm{O}_{2}$, and $100 \mu \mathrm{L}$ of crude enzyme. The activity is expressed as $\mathrm{mM}$ per $\mathrm{mg}$ of fresh weight. A cut flower was removed from the vase solution on the $5^{\text {th }}$ day; measurement of SOD was done using spectrophotometry by Giannopolitis and Ries (1997) method from petal tissue.

\section{Statistical analysis}

The variance of data was analyzed in SAS statistical software, and means were compared by the least significant difference (LSD) test at the 0.05 and 0.01 of probability level.

\section{Results and Discussion}

Significant differences $(\mathrm{p} \leq 0.01$ and $\mathrm{p} \leq 0.05)$ were obtained for the vase life of Rosa hybrida L. after treatment of cut flowers with warm water, and interaction effect between warm water and time duration. No significant difference was found for the vase life of cut flowers after time treatment (Table 1). Treatment of cut flowers with water at temperature of $52{ }^{\circ} \mathrm{C}$ for 15 min resulted in longer vase life ( 7.75 days) than control (4.46 days). Besides that, the average vase life increased for cut flowers pre-treated with water at temperature of $52{ }^{\circ} \mathrm{C}$ for $5 \mathrm{~min}$ and water with temperature at $47^{\circ} \mathrm{C}$ for 15 min (both with 7.42 days' vase life) (Table 2). Totally, exposure of cut flowers with warm water for 15 min was the best to extend postharvest longevity. In most cases, exposure of cut flowers with warm water for 15 min was not good to extend postharvest longevity.

The current study showed that warm water treatment delays senescence of cut $R$. hybrida flowers and prolong its postharvest longevity by delaying fresh weight loss and degradation of chlorophylls and anthocyanin, increasing water uptake, decreasing ethylene production, and changing antioxidant activity. This finding is like that of other studies. Woolf et al. (2012) have shown that postharvest hot water treatments can successfully decrease both incidence and severity of leaf senescence in Asiatic hybrid lilies, as well as delaying its onset. Hamidi et al. (2020) reported that hot water treatment is effective in increasing the vase life of cut rose flowers. Opio et al. (2017) showed that treatment of lime fruit with hot water could reduce the chlorophyll degradation and inhibited ethylene production, as well as respiration during the early stages of storage. Heat can shift protein synthesis to the production of heat shock proteins, rather than a direct effect of heat on specific enzymes involved in senescence (Woolf et al., 2012). The treatment of cut Lilium flower with hot water $\left(50^{\circ} \mathrm{C}\right.$ for $5 \mathrm{~min}$ or $52.5^{\circ} \mathrm{C}$ for $\left.2.5 \mathrm{~min}\right)$ effectively increased the vase life and reduced leaf yellowing (Woolf et al., 2012).

Treatment of cut flowers with water at temperature of $23^{\circ} \mathrm{C}$ for $15 \mathrm{~min}$ and water at temperature of $47^{\circ} \mathrm{C}$ for 15 min (with 2.62 and $2.81 \mathrm{~g}$, respectively) resulted in the lowest decrease in fresh weight (Table 2). The highest decrease in fresh weight (7.68 g) was recorded in untreated (control) cut flowers (Table 2). The cut flowers treated at $52{ }^{\circ} \mathrm{C}$ for $10 \mathrm{~min}$ exhibited a high level of fresh weight loss. The increase in treatments was not directly correlated with the increase in fresh weight. Data analysis showed

Table 1. Analysis of variance of the effect of hot water and its time duration on various characteristics of cut rose (Rosa hybrida) flowers.

\begin{tabular}{|l|c|c|c|c|c|c|c|c|}
\hline Source of variations & df & Vase life & $\begin{array}{c}\text { Water } \\
\text { absorption }\end{array}$ & $\begin{array}{c}\text { Weight } \\
\text { loss }\end{array}$ & ${ }^{\circ}$ Brix & $\begin{array}{c}\text { Dry } \\
\text { matter }\end{array}$ & $\begin{array}{c}\text { Anthocyanin } \\
\text { peroxidation }\end{array}$ \\
\hline Temperature (A) & 3 & $4.39^{* *}$ & $2.01^{*}$ & $7.58^{* *}$ & $0.60^{* *}$ & $170.00^{* *}$ & $782.00^{* *}$ & $5.82^{* *}$ \\
\hline Time (B) & 3 & $1.36^{\text {ns }}$ & $0.84^{* *}$ & $8.82^{* *}$ & $0.22^{\text {ns }}$ & $10.59^{\text {ns }}$ & $22.32^{* *}$ & $1.44^{* *}$ \\
\hline A $\times$ B & 9 & $2.08^{*}$ & $1.14^{* *}$ & $4.50^{* *}$ & $1.58^{* *}$ & $72.42^{*}$ & $90.42^{* *}$ & $0.41^{\text {ns }}$ \\
\hline Error & 32 & 0.84 & 0.13 & 0.63 & 0.35 & 25.21 & 0.65 & 0.23 \\
\hline CV (\%) & & 13.58 & 13.58 & 17.44 & 16.5 & 13.04 & 3.67 & 5.46 \\
\hline Source of variations & df & Ethylene & Chl. a & Chl. b & Total chl. & POD & SOD & MDA \\
\hline Temperature (A) & 3 & $1,726.00^{* *}$ & $6.96^{* *}$ & $3.54^{* *}$ & $20.32^{* *}$ & $3.43^{* *}$ & $477.00^{* *}$ & $259.00^{* *}$ \\
\hline Time (B) & 3 & $88.52^{* *}$ & $0.98^{* *}$ & $0.01^{\text {ns }}$ & $1.21^{* *}$ & $1.57^{* *}$ & $17.98^{* *}$ & $13.30^{\text {ns }}$ \\
\hline A $\times$ B & 9 & $274.00^{* *}$ & $0.98^{* *}$ & $0.16^{* *}$ & $1.60^{* *}$ & $0.75^{* *}$ & $231.00^{* *}$ & $228.60^{* *}$ \\
\hline Error & 32 & 14.18 & 0.01 & 0.025 & 0.03 & 0.11 & 4.00 & 16.08 \\
\hline CV (\%) & & 8.65 & 3.56 & 15.95 & 6.51 & 13.51 & 4.58 & 3.38 \\
\hline
\end{tabular}

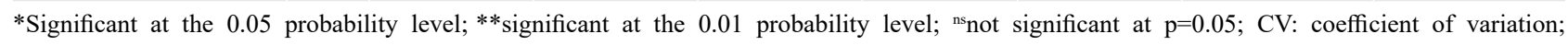
POD: peroxidase; SOD: superoxide dismutase; MDA: malondialdehyde. 
Table 2. Mean comparison of the effect of hot water and its time duration on various characteristics of cut rose (Rosa hybrida) flowers*.

\begin{tabular}{|c|c|c|c|c|c|c|c|}
\hline Treatments & Vase life & $\begin{array}{c}\text { Water } \\
\text { absorption }\end{array}$ & Weight loss & ${ }^{\circ}$ Brix & Dry matter & Anthocyanin & $\begin{array}{c}\text { Lipid } \\
\text { peroxidation }\end{array}$ \\
\hline $\mathrm{A}_{1} \mathrm{~B}_{1}$ & $4.46^{\mathrm{d}}$ & $0.83^{\mathrm{g}}$ & $7.68^{\mathrm{a}}$ & $3.16^{\text {cde }}$ & $33.24^{\mathrm{def}}$ & $9.17^{j}$ & 9.40 \\
\hline $\mathrm{A}_{1} \mathrm{~B}_{2}$ & $6.70^{\mathrm{abc}}$ & $1.61^{\mathrm{ef}}$ & $5.98^{\mathrm{bc}}$ & $2.76^{\mathrm{de}}$ & $36.51^{\text {cde }}$ & $19.68^{\mathrm{g}}$ & 8.91 \\
\hline $\mathrm{A}_{1} \mathrm{~B}_{3}$ & $7.41^{\mathrm{a}}$ & $2.37^{\mathrm{bcd}}$ & $3.98^{\text {efgh }}$ & $3.60^{\mathrm{abcd}}$ & $42.01^{\mathrm{abc}}$ & $12.77^{\mathrm{i}}$ & 8.21 \\
\hline $\mathrm{A}_{1} \mathrm{~B}_{4}$ & $7.06^{\mathrm{ab}}$ & $2.34^{\mathrm{bcd}}$ & $4.64^{\mathrm{def}}$ & $3.73^{\mathrm{abcd}}$ & $38.20^{\text {abcde }}$ & $13.16^{\mathrm{i}}$ & 9.23 \\
\hline $\mathrm{A}_{2} \mathrm{~B}_{1}$ & $7.40^{\mathrm{a}}$ & $2.90^{\mathrm{abc}}$ & $3.77^{\text {efghi }}$ & $4.18^{\mathrm{ab}}$ & $36.94^{\text {bcde }}$ & $25.20^{\mathrm{de}}$ & 8.08 \\
\hline $\mathrm{A}_{2} \mathrm{~B}_{2}$ & $6.09^{\mathrm{abc}}$ & $1.36^{\mathrm{fg}}$ & $5.04^{\text {cde }}$ & $3.00^{\mathrm{de}}$ & $42.55^{\mathrm{abc}}$ & $25.00^{\text {de }}$ & 8.41 \\
\hline $\mathrm{A}_{2} \mathrm{~B}_{3}$ & $7.42^{\mathrm{a}}$ & $1.98^{\mathrm{def}}$ & $2.81^{\mathrm{hi}}$ & $4.17^{\mathrm{ab}}$ & $41.24^{\mathrm{abcd}}$ & $24.07^{\mathrm{e}}$ & 8.44 \\
\hline $\mathrm{A}_{2} \mathrm{~B}_{4}$ & $7.40^{\mathrm{a}}$ & $1.67^{\mathrm{ef}}$ & $5.33^{\mathrm{cd}}$ & $3.58^{\mathrm{abcd}}$ & $45.14^{\mathrm{ab}}$ & $33.61^{\mathrm{b}}$ & 8.22 \\
\hline $\mathrm{A}_{3} \mathrm{~B}_{1}$ & $7.42^{\mathrm{a}}$ & $2.70^{\mathrm{bc}}$ & $3.72^{\text {fghi }}$ & $4.17^{\mathrm{ab}}$ & $41.08^{\mathrm{abcde}}$ & $31.88^{c}$ & 8.60 \\
\hline $\mathrm{A}_{3} \mathrm{~B}_{2}$ & $7.40^{\mathrm{a}}$ & $2.92^{\mathrm{ab}}$ & $6.99^{\mathrm{ab}}$ & $4.56^{\mathrm{a}}$ & $45.39^{\mathrm{a}}$ & $26.07^{d}$ & 7.96 \\
\hline $\mathrm{A}_{3} \mathrm{~B}_{3}$ & $7.42^{\mathrm{a}}$ & $3.37^{\mathrm{a}}$ & $4.64^{\mathrm{def}}$ & $2.56^{\mathrm{e}}$ & $40.21^{\text {abcde }}$ & $38.27^{\mathrm{a}}$ & 8.01 \\
\hline $\mathrm{A}_{3} \mathrm{~B}_{4}$ & $7.40^{\mathrm{a}}$ & $1.91^{\mathrm{def}}$ & $3.32^{\text {ghi }}$ & $2.80^{\mathrm{de}}$ & $38.94^{\text {abcde }}$ & $25.92^{\mathrm{d}}$ & 8.98 \\
\hline $\mathrm{A}_{4} \mathrm{~B}_{1}$ & $6.73^{\mathrm{abc}}$ & $1.85^{\mathrm{def}}$ & $4.62^{\operatorname{defg}}$ & $3.41^{\text {bcde }}$ & $40.88^{\text {abcde }}$ & $21.26^{\mathrm{f}}$ & 10.19 \\
\hline $\mathrm{A}_{4} \mathrm{~B}_{2}$ & $5.45^{\mathrm{cd}}$ & $1.65^{\mathrm{ef}}$ & $3.90^{\text {efghi }}$ & $4.00^{\mathrm{abc}}$ & $25.12^{\mathrm{f}}$ & $9.58^{\mathrm{j}}$ & 9.66 \\
\hline $\mathrm{A}_{4} \mathrm{~B}_{3}$ & $5.74^{\mathrm{bcd}}$ & $2.31^{\mathrm{cd}}$ & $2.62^{\mathrm{i}}$ & $4.27^{\mathrm{ab}}$ & $32.82^{\mathrm{ef}}$ & $17.90^{\mathrm{h}}$ & 9.04 \\
\hline $\mathrm{A}_{4} \mathrm{~B}_{4}$ & $6.42^{\mathrm{abc}}$ & $2.31^{\mathrm{cd}}$ & $3.61^{\text {fghi }}$ & $3.53^{\text {bcde }}$ & $35.48^{\text {cde }}$ & $17.62^{\mathrm{h}}$ & 10.34 \\
\hline Treatments & Ethylene & Chl. a & Chl. b & Total chl. & POD & SOD & MDA \\
\hline $\mathrm{A} 1 \mathrm{~B} 1$ & $31.95 \mathrm{~m}$ & $0.93 \mathrm{i}$ & $0.34 \mathrm{~g}$ & $1.27 \mathrm{j}$ & $3.72 \mathrm{a}$ & $57.90 \mathrm{a}$ & $124.80 \mathrm{a}$ \\
\hline A1B2 & $35.78 \mathrm{k}$ & $1.40 \mathrm{fg}$ & $0.73 \mathrm{def}$ & $2.12 \mathrm{~g}$ & $3.65 \mathrm{ab}$ & $53.00 \mathrm{~b}$ & $120.00 \mathrm{abcd}$ \\
\hline A1B3 & $42.24 \mathrm{~h}$ & $0.82 \mathrm{j}$ & $0.46 f g$ & $1.28 \mathrm{j}$ & $2.20 \mathrm{de}$ & $34.78 \mathrm{f}$ & $125.42 \mathrm{a}$ \\
\hline A1B4 & $45.06 \mathrm{f}$ & $1.43 \mathrm{f}$ & $0.51 \mathrm{efg}$ & $1.94 \mathrm{gh}$ & $1.67 \mathrm{ef}$ & $35.43 \mathrm{f}$ & $124.03 \mathrm{ab}$ \\
\hline $\mathrm{A} 2 \mathrm{~B} 1$ & $29.74 n$ & $1.78 \mathrm{e}$ & $1.43 b c$ & $3.21 \mathrm{e}$ & $1.90 \mathrm{de}$ & $33.87 \mathrm{fg}$ & $124.33 \mathrm{ab}$ \\
\hline A2B2 & $39.29 \mathrm{j}$ & $1.86 \mathrm{e}$ & $1.26 \mathrm{c}$ & $3.12 \mathrm{e}$ & $2.15 \mathrm{de}$ & $32.31 \mathrm{fg}$ & $124.65 \mathrm{ab}$ \\
\hline $\mathrm{A} 2 \mathrm{~B} 3$ & $41.77 \mathrm{i}$ & $1.83 \mathrm{e}$ & $0.96 \mathrm{c}$ & $2.79 f$ & $2.20 \mathrm{de}$ & $47.19 \mathrm{~cd}$ & $113.90 \mathrm{de}$ \\
\hline A2B4 & 32.97 & $3.80 \mathrm{a}$ & $1.64 \mathrm{ab}$ & $5.44 \mathrm{a}$ & $2.23 \mathrm{f}$ & $31.44 \mathrm{~g}$ & $118.00 \mathrm{bcd}$ \\
\hline A3B1 & $51.28 \mathrm{e}$ & $3.17 \mathrm{~b}$ & $1.56 \mathrm{~b}$ & $4.73 b$ & $2.31 d$ & $42.71 \mathrm{e}$ & $94.10 \mathrm{f}$ \\
\hline A3B2 & $44.57 \mathrm{~g}$ & $2.20 \mathrm{~d}$ & $1.49 \mathrm{bc}$ & $3.69 \mathrm{~d}$ & $2.30 \mathrm{~d}$ & $40.96 \mathrm{e}$ & $118.80 \mathrm{abcd}$ \\
\hline A3B3 & $27.78 p$ & $2.38 \mathrm{c}$ & $1.90 \mathrm{a}$ & $4.27 \mathrm{c}$ & $2.40 \mathrm{~d}$ & $41.40 \mathrm{e}$ & $120.00 \mathrm{abcd}$ \\
\hline A3B4 & 29.150 & $2.34 \mathrm{c}$ & $1.46 \mathrm{bc}$ & $3.79 d$ & $2.20 \mathrm{de}$ & $42.00 \mathrm{e}$ & $121.00 \mathrm{abc}$ \\
\hline A4B1 & $74.49 a$ & $1.31 \mathrm{~g}$ & $0.76 \mathrm{de}$ & $2.07 \mathrm{~g}$ & $3.16 \mathrm{abc}$ & $43.93 \mathrm{de}$ & $122.86 \mathrm{ab}$ \\
\hline A4B2 & $52.92 \mathrm{~d}$ & $0.87 \mathrm{ij}$ & $0.41 \mathrm{~g}$ & $1.28 \mathrm{j}$ & $3.10 b c$ & $48.81 \mathrm{c}$ & $110.40 \mathrm{e}$ \\
\hline A4B3 & $64.62 b$ & $1.06 \mathrm{~h}$ & $0.59 \mathrm{efg}$ & $1.65 \mathrm{hi}$ & $3.05 c$ & $53.69 \mathrm{~b}$ & $116.00 \mathrm{cde}$ \\
\hline A4B4 & $53.95 \mathrm{c}$ & $1.05 \mathrm{~h}$ & $0.56 \mathrm{efg}$ & $1.60 \mathrm{i}$ & $2.99 \mathrm{c}$ & $58.58 \mathrm{a}$ & $111.00 \mathrm{e}$ \\
\hline
\end{tabular}

*Means with different letters on the same column are significantly different $(\mathrm{p}<0.05)$ based on LSD test. $\mathrm{A}_{1}, \mathrm{~A}_{2}, \mathrm{~A}_{3}$, and $\mathrm{A}_{4}$ : Hot water at temperature of $23^{\circ}, 42^{\circ}, 47^{\circ}$, and $52^{\circ} \mathrm{C}$, respectively; $\mathrm{B}_{1}, \mathrm{~B}_{2}, \mathrm{~B}_{3}$, and $\mathrm{B}_{4}$ : Time duration of 5, 10, 15, and 20 min, respectively; POD: peroxidase; SOD: superoxide dismutase; MDA: malondialdehyde.

that the effect of different temperatures of water and exposure time was significant on the loss of fresh weight $(\mathrm{p} \leq 0.01)$ (Table 1). Dry matter percentage increased in cut flowers treated with $52^{\circ} \mathrm{C}$ for $10 \mathrm{~min}(45.39 \%)$ compared to the control $(33.24 \%$ ) (Table 2). Minimum dry matter percentage $(25.12 \%)$ was obtained in cut flowers treated with warm water at $23^{\circ} \mathrm{C}$ for $10 \mathrm{~min}$ (Table 2). Significant differences $(\mathrm{p} \leq 0.01$ and $\mathrm{p} \leq 0.05)$ were obtained for dry matter percentage of $R$. hybrida L. after treatment of cut flowers with warm water, and interaction effect between warm water and time duration. Time treatment did not cause any significant differences in the dry matter percentage of cut flowers (Table 1). Control cut flower showed the lowest rate of water uptake $\left(0.83 \mathrm{mg} \mathrm{g}^{-1} \mathrm{FW}\right)$. The highest water uptake was observed in cut flowers treated with warm water $\left(52^{\circ} \mathrm{C}\right)$ for $15 \mathrm{~min}$. (Table 2). The water uptake of warm water treated cut flowers was higher than the control. Statistical analysis (ANOVA) of data showed that the effect of temperature $(p \leq 0.05)$, time duration $(p \leq 0.01)$, and interaction effect of these two factors $(p \leq 0.01)$ on water 
absorption was significant (Table 1). As seen in Table 2, many warm water treatments showed high Brix when compared to the control, and the difference was significant $(\mathrm{p} \leq 0.01)$. Time treatment had no significant difference on Brix (Table 1). The highest Brix was observed in cut flowers treated with warm water at $52^{\circ} \mathrm{C}$ for $10 \mathrm{~min}$ (Table 2), and the lowest one was related to those treated with warm water at $52^{\circ} \mathrm{C}$ for $15 \mathrm{~min}$. The application of warm water at all concentrations delayed the anthocyanin degradation in comparison to control (Table 2). Results obtained in this study on measurement of petal's anthocyanin showed that the cut flowers treated with warm water at $52^{\circ} \mathrm{C}$ for 15 min significantly had more anthocyanin content (38.27 $\mathrm{g} \mathrm{g} \mathrm{g}^{-1}$ F.W.) in comparison to the other treatments and untreated control. The least petal's anthocyanin was obtained in control cut flowers. The difference in the content of petal's anthocyanin between cut flowers treated and untreated was significant (Table 1). The application of warm water at all concentrations delayed the total chlorophyll degradation in comparison to control (Table 2). Results obtained with spectrophotometer showed that the cut flowers treated with warm water at $47^{\circ} \mathrm{C}$ for $20 \mathrm{~min}$ significantly had more leaf chlorophyll content $\left(5.44 \mathrm{mg} \mathrm{g}^{-1}\right.$ F.W.) in comparison to the other treatments and untreated control (Tables 1 and 2). Minimum chlorophyll content was calculated in control cut flowers. All treatments markedly reduced ethylene production in cut $R$. hybrida L. flowers $(\mathrm{p} \leq 0.01)$ compared to the control (Table 1). The least ethylene production $\left(27.78 \mathrm{nl} \mathrm{L}^{-1} \mathrm{~g}^{-1} \mathrm{FW}\right)$ was devoted to in cut flowers treated by warm water at $52^{\circ} \mathrm{C}$ for $15 \mathrm{~min}$ (Table 2). This treatment reduced about $60 \%$ ethylene production compared to the control (Table 2). Interaction between different temperatures of water and time treatment was significant at $\mathrm{p} \leq 0.01$ on ethylene production of cut flowers (Table 1). The highest amount of ethylene production was calculated in flowers treated with warm water at $23^{\circ} \mathrm{C}$ for $5 \mathrm{~min}$ (Table 2). Information obtained from means comparison of data revealed that the control cut flowers produced more MDA than the other cut flowers treated with different temperatures and time duration warm water (Table 2). Thus, control cut flowers exhibited the highest MDA content (124.80 nmol g-1 F.W.), whereas the lowest one ( $94.10 \mathrm{nmol} \mathrm{g}^{-1} \mathrm{~F}$.W.) was obtained from the cut flowers treated with warm water at $52^{\circ} \mathrm{C}$ for 5 min (Table 2). The activity of the POD enzyme changed as temperature and time of water exposure altered. Maximum activity of the POD enzyme (3.72 nmol g-1 F.W.) was observed in control cut flowers $\left(42^{\circ} \mathrm{C}\right.$ for $\left.5 \mathrm{~min}\right)$ (Table 2$)$, and its activity in cut flowers treated with warm water at $42^{\circ} \mathrm{C}$ for $10 \mathrm{~min}\left(3.65 \mathrm{nmol} \mathrm{g}^{-1} \mathrm{~F}\right.$.W. $)$ was at a good level and greater than the activity of the other treatments (Table 2). The minimum activity of the POD enzyme $\left(1.67 \mathrm{nmol} \mathrm{g}^{-1}\right.$ F.W.) was observed in cut flowers treated by warm water with $42^{\circ} \mathrm{C}$ for $20 \mathrm{~min}$. (Table 2). A significant difference $(\mathrm{p} \leq 0.01)$ was obtained for the POD enzyme activity of Rosa hybrida L. after treatment of cut flowers with warm water, time duration, and the interaction effect between warm water and time duration (Table 1). The activity of the SOD enzyme changed with temperature and duration of water exposure. The maximum activity of the SOD enzyme $\left(58.58 \mathrm{nmol} \mathrm{g}^{-1}\right.$ F.W.) was related to cut flowers treated with warm water at $23^{\circ} \mathrm{C}$ for $20 \mathrm{~min}$ (Table 2). Activity of this enzyme in control cut flowers $\left(42^{\circ} \mathrm{C}\right.$ for $\left.5 \mathrm{~min}\right)$ with 57.90 nmol $\mathrm{g}^{-1}$ F.W. was also greater than its activity in other treatments (Table 2). The minimum activity of the SOD enzyme (31.44 and $32.31 \mathrm{nmol} \mathrm{g}^{-1}$ F.W.) was associated with cut flowers treated with warm water at $47^{\circ} \mathrm{C}$ for 20 and $10 \mathrm{~min}$, respectively (Table 2).

Heat treatment can be used to inhibit ripening processes or to induce resistance to pathogens during storage, thus extending storability and marketing (Perini et al., 2017; Francesco et al., 2018; Zhang et al., 2019). It has been reported that the vase life of flowers that were exposed to postharvest hot-air conditioning prior to hot water immersion $\left(49^{\circ} \mathrm{C}\right.$ for $\left.12 \mathrm{~min}\right)$ equaled or outperformed the vase life of flowers treated in hot water immersion only or untreated (Hara et al., 1997). Similar treatments resulted in a decrease in the geotropism response, thus extending the vase life of the flower (Jaroenkit and Paull, 2003). However, hot water treatments did not benefit some flowers, such as Heliconia spp. and Strelitzia reginae (Jaroenkit and Paull, 2003).

\section{Conclusions}

In conclusion, warm water has the potential of extending the vase life of cut Rosa hybrida L. flowers. Heat treatments are being applied in horticulture, including maintenance of freshness and reduced senescence. The vase life of cut R. hybrida flowers was found to be possibly extended by using warm water $\left(52^{\circ} \mathrm{C}\right)$ for $15 \mathrm{~min}$.

\section{Author contribution}

DH: conceptualization, investigation, methodology, formal analysis, writing original draft, writing review and editing. BK: formal analysis, writing original draft, writing review and editing. NN: methodology, formal analysis. SE: data curation, methodology, writing original draft. FZ: data curation, methodology.

\section{Acknowledgements}

The authors would like to thank the Islamic Azad University, Rasht Branch, Rasht, Iran.

\section{References}

BASSAL, M.; EL-HAMAHMY, M. Hot water dip and preconditioning treatments to reduce chilling injury and maintain postharvest quality of Navel and Valencia oranges during cold quarantine. Postharvest Biology and Technology, v.60, n.3, p.186-191, 2011. https://doi. org/10.1016/j.postharvbio.2011.01.010

BATES, L.S.; WALDREN, R.P.; TEARE, I.D. Rapid determination of free proline for water-stress studies. Plant Soil, v.39, p.205-207, 1973. https://doi.org/10.1007/ BF00018060 
FRANCESCO, A.D.; MARI, M.; ROBERTI, R. Defense response against postharvest pathogens in hot water treated apples. Scientia Horticulturae, v.227, p.181-186, 2018. https://doi.org/10.1016/j.scienta.2017.09.039

GHADIMIAN, S.; DANAEI, E. Influences of ascorbic acid and salicylic acid on vase life of cut flowers rose (Rosa hybrida cv. Black magic). Alkhas, v.2, n 1, p.1-6, 2020. https://doi.org/10.29252/alkhass.2.1.1

GIANNOPOLITIS, C.; RIES, S. Superoxide dismutase I: occurrence in higher plant. Plant Physiology, v.59, n.2, p.309-314, 1997. https://doi.org/10.1104/pp.59.2.309

HAMIDI, E.; ROEIN, Z.; KARIMI, M. Extending the vase life of rose cut flower cv. Bakara using inhibitors of physiological vascular occlusion. Journal of Horticulture and Postharvest Research, v.3, n.1, p.35-48, 2020. https:// doi.org/1072.2594.2019.jhpr/22077.1

HARA, A.H.; HATA, T.Y.; HU, B.K.S.; TSANG, M.M.C. Hot-air induced thermos tolerance of red ginger flowers and mealy bugs to postharvest hot-water immersion. Postharvest Biology and Technology, v.12, n.1, p.101-108, 1997. https://doi.org/10.1016/S09255214(97)00042-2

HEATH, R.L.; PARKER, L. Photoperoxidation in isolated chloroplasts: I. Kinetics and stiochiometry of fatty acid peroxidation. Archives of Biochemistry and Biophysics, v.125, n.1, p.189-198, 1968. https://doi.org/10.1016/00039861(68)90654-1

JAROENKIT, T.; PAULL, R.E. Postharvest handling of Heliconia, red ginger and bird-of-paradise. HortTechnology, v.13, n.2, p.259-266, 2003. https://doi. org/10.21273/HORTTECH.13.2.0259

KAZAZ, S.; DOGAN, E.; KILIC, T.; SAHIN, E.G.E.; SEYHAN, S. Influence of holding solutions on vase life of cut hydrangea flowers (Hydrangea macrophylla Thunb.). Fresenius Environmental Bulletin, v.28, n.4, p.35543559, 2019.

LEUS, L.; VAN LAERE, K.; DE RIEK, J.; VAN HUYLENBROECK, J.R. VAN HUYLENBROECK, J. Ornamental Crops, Hand book of Plant Breeding. Berlin: Springer, 2018. p.719-767.
LU, N.; WU, L.; SHI, M. Selenium enhances the vase life of Lilium longiflorum cut flower by regulating postharvest physiological characteristics. Scientia Horticulturae, v.264, 109172, 2020. https://doi.org/10.1016/j. scienta.2019.109172

MAZUMDAR, B.C.; MAJUMDER, K. Methods on Physico Chemical Analysis of Fruits. New Delhi: Daya, 2003.

MINDE, $H$. The effects of different vase solutions on the postharvest life of rose flower- review. Journal of Natural Sciences Research, v.9, n.5, p.10-16, 2019. https://doi. org/10.7176/JNSR/9-5-02

NASEF, I.N. Short hot water as safe treatment induces chilling tolerance and anti-oxidant enzymes, prevents decay and maintains quality of cold-stored cucumbers. Postharvest Biology and Technology, v.138, p.1-10, 2018. https://doi.org/10.1016/j.postharvbio.2017.12.005

OPIO, P.; JITAREERAT, P.; PONGPRASERT, N.; WONGS-AREE, C.; SUZUKI, Y.; SRILAONG, V. Efficacy of hot water immersion on lime (Citrus auranifolia, Swingle cv. Paan) fruit packed with ethanol vapor in delaying chlorophyll catabolism. Scientia Horticulturae, v.224, p.258-264, 2017. https://doi.org/10.1016/j. scienta.2017.06.034

PERINI, M.A.; SIN, I.N.; REYES JARA, A.M.; GÓMEZ LOBATO, M.E.; CIVELLO, P.E.; MARTÍNEZ, G.E. Hot water treatments performed in the base of the broccoli stem reduce postharvest senescence of broccoli (Brassica oleracea L. var italic) heads stored at $20^{\circ} \mathrm{C}$. LWT, v.77, p.314-322, 2017. https://doi.org/10.1016/j.lwt.2016.11.066

WOOLF, A.B.; COMBES, S.; PETLEY, M.; OLSSON, S.R.; WOHLERS, M.; JACKMAN, R.C. Hot water treatments reduce leaf yellowing and extend vase life of Asiatic hybrid lilies. Postharvest Biology and Technology, v.64, n.1, p.9-18, 2012. https://doi.org/10.1016/j. postharvbio.2011.09.012

ZHANG, M.; LIU, W.; LI, C.; SHAO, T.; JIANG, X.; ZHAO, H.; AI, W. Postharvest hot water dipping and hot water forced convection treatments alleviate chilling injury for zucchini fruit during cold storage. Scientia Horticulturae, v.249, p.219-227, 2019. https://doi. org/10.1016/j.scienta.2019.01.058 